\title{
RECONSIDERING THE NECESSARY BEINGS OF AQUINAS'S THIRD WAY
}

\author{
GREGORY J. ROBSON
}

Duke University

\begin{abstract}
Surprisingly few articles have focused on Aquinas's particular conception of necessary beings in the Third Way, and many scholars have espoused inaccurate or incomplete views of that conception. My aim in this paper is both to offer a corrective to some of those views and, more importantly, to provide compelling answers to the following two questions about the necessary beings of the Third Way. First, how exactly does Aquinas conceive of these necessary beings? Second, what does Aquinas seek to accomplish (and what does he accomplish) in the third stage of the Third Way? In answering these questions, I challenge prominent contemporary understandings of the necessary beings of the Third Way.
\end{abstract}

\section{INTRODUCTION}

In the sizeable literature on Aquinas's Third Way, ${ }^{1}$ much attention has been paid to certain features of the argument, such as its alleged quantifier fallacy. ${ }^{2}$ There has also been discussion of Aquinas's general conception of

\footnotetext{
${ }^{1}$ Perhaps the best bibliography of both historical and contemporary discussion can be found in Wippel, The Metaphysical Thought of Thomas Aquinas, pp. 597-616. For illuminating contemporary discussion, see: “Aquinas's Third Way" (Davies, pp. 450-466); The Five Ways (Kenny, pp. 46-69); Approaches to God (Maritain, pp. 43-49); Thomas Aquinas: God and Explanations (Martin, pp. 155-170); and The Metaphysical Thought of Thomas Aquinas (Wippel, pp. 462-469).

${ }^{2}$ See, e.g.: Brian Shanley, The Thomist Tradition, p. 184; C. F. J. Martin, Thomas Aquinas: God and Explanations, p. 161.
} 
necessary beings. ${ }^{3}$ Yet surprisingly few articles have focused on Aquinas's particular conception of necessary beings in the Third Way, and many scholars have espoused inaccurate or incomplete views of that conception. ${ }^{4}$ My aim in this paper is both to offer a corrective to some of those views and, more importantly, to provide compelling answers to the following two questions about the necessary beings of the Third Way. ${ }^{5}$ First, how exactly does Aquinas conceive of these necessary beings? Second, what does Aquinas seek to accomplish (and what does he accomplish) in the third stage of the Third Way? Scholars have offered various answers to the first question; I will attempt to separate the wheat from the chaff. Concerning the second question, too, there are various views circulating in the scholarship. I will defend the view that, if Aquinas fails to prove that the uncaused, necessary being arrived at in the Third Way is, in fact, God (in the sense of a proper name), this failure is of trivial importance when understood in the context of his overall project in the Prima Pars. In answering both questions, I will challenge prominent contemporary understandings of the necessary beings of the Third Way.

Section I of this paper presents the text of the Third Way, unpacks its argument, and situates that argument in the broader context of Aquinas's relevant views. Section II homes in on Aquinas's nuanced conception of necessary beings, teasing out relevant distinctions, depicting the conception diagrammatically, and countering selected misinterpretations of it. (Note that I use "god" and "God" interchangeably in Sections I and II; Section III is where I tease out and highlight the importance of that distinction.) Section III addresses one of the most salient criticisms of the third stage of the Third Way, namely, the claim that Aquinas has not successfully demonstrated the existence of God (note the proper name

\footnotetext{
${ }^{3}$ See: Brown, "St. Thomas's Doctrine of Necessary Being”.

${ }^{4}$ In fact, Brown's is the closest approximation I have come across to such an article. Yet, as noted above, his article focuses on Aquinas's general conception of necessary beings, rather than primarily on necessary beings vis-à-vis the Third Way. As to scholars holding inaccurate or incomplete views of the Third Way, this fact will be highlighted throughout the paper.

${ }^{5}$ Aquinas also offers a proof of God's existence in the Summa Contra Gentiles that is similar to the better known proof of the Third Way (see: SCG I, c. 15): "Every necessary being, however, either has the cause of its necessity in an outside source or, if it does not, it is necessary through itself. But one cannot proceed to infinity among necessary beings the cause of whose necessity lies in an outside source. We must therefore posit a first necessary being, which is necessary through itself." For illuminating discussion of SCG I, c. 15, see: Wippel, pp. 435-440.
} 
"God"). It then suggests that this criticism overlooks both Aquinas's aims in the Third Way and the role that the Third Way plays in part of a broader line of argument in the Prima Pars. ${ }^{6}$

\section{THE THIRD WAY: TEXT AND CONTEXT}

The Third Way is found in q. 2 of the Prima Pars, where Aquinas asks whether the proposition "God exists" is self-evident; whether God's existence is demonstrable; and whether God actually exists. Aquinas argues that the proposition "God exists" is not self-evident to us (i.e., not per se notum). ${ }^{7}$ Knowledge of God's existence must be acquired, specifically via a posteriori demonstration through God's effects. (An a priori demonstration of God's existence is not possible, says Aquinas, since we cannot know God's essence prior to knowing God's existence.) Accordingly, Aquinas undertakes an a posteriori demonstration of God's existence in the Third Way. ${ }^{8}$

The Third Way is a causal argument that posits the existence of an uncaused, necessary being in order to account for: (1) the existence of possible (we may say "contingent") beings that are readily observable in the world; and (2) the metaphysically necessary facts that the world cannot exclusively consist of contingent beings, nor include infinitely many necessary beings whose necessity owes to some other being. To get some purchase on the Third Way, it is useful to go directly to ST I, q. 2, art. 3, where Aquinas writes:

The third way is taken from possibility and necessity, and runs thus. We find in nature things that are possible to be and not to be, since they are found to be generated, and to corrupt, and consequently, they are possible to be and not to be. But it is impossible for these always to exist, for that which is possible not to be at some time is not. Therefore,

\footnotetext{
${ }^{6}$ I am grateful to Marilyn McCord Adams for her generous feedback on an earlier version of this paper.

${ }^{7}$ Aquinas, Summa Theologica, I, q. 2, art. 1. Aquinas rejects views at each extreme: one, that God's existence is self-evident to us; the other, that one should be agnostic about God's existence. Aquinas also notes, in SCG I, cc. 10-12, that God cannot be self-evident to us, since we do not know what God's essence is (see: Wippel, pp. 386, 389). Though we can know God, we cannot know God essentially.

${ }^{8}$ According to Aquinas, demonstration is possible either through the cause of the thing to be demonstrated (a priori demonstration) or through its effect (a posteriori demonstration). Later in the paper, I indicate why the Third Way is a demonstration quia.
} 
if everything is possible not to be, then at one time there could have been nothing in existence. Now if this were true, even now there would be nothing in existence, because that which does not exist only begins to exist by something already existing. Therefore, if at one time nothing was in existence, it would have been impossible for anything to have begun to exist; and thus even now nothing would be in existence - which is absurd. Therefore, not all beings are merely possible, but there must exist something the existence of which is necessary. But every necessary thing either has its necessity caused by another, or not. Now it is impossible to go on to infinity in necessary things which have their necessity caused by another, as has been already proved in regard to efficient causes. Therefore we cannot but postulate the existence of some being having of itself its own necessity, and not receiving it from another, but rather causing in others their necessity. This all men speak of as God. ${ }^{9}$

The Third Way is a three-staged argument. In the first stage, Aquinas argues that it is not possible for beings that can be and not be always to exist. In the second stage, he seeks to demonstrate that some necessary being must exist. It is clear from the first two stages that Aquinas is offering a cosmological argument. We start with a relatively straightforward observation about the world and then move towards the conclusion that a necessary being must exist. The straightforward observation is that we find in nature things that are generated and corrupted. From his Aristotelian perspective, Aquinas believes that all material things are hylomorphic composites that can, by their nature, exist at one point in time and not exist at another. Such things - i.e., possibles ${ }^{10}$ or contingent beings - are produced into being and naturally tend to cease existing at some point. ${ }^{11}$ For it is in the nature of contingent beings to cease existing, and the failure of some contingent being $\mathrm{C}$ to cease existing would be contrary, not only to C's nature, but also to the causal system in which

${ }^{9}$ Aquinas, Summa Theologica, I, q. 2, art. 3. The brevity of the Third Way and the need to pay careful attention to the text make it worthwhile to include this passage in whole.

${ }^{10}$ Wippel tells us that a possible being is, for Aquinas, one "which comes into existence by generation" (Wippel, p. 465).

${ }_{11}$ Intellectual historians might wish to note the striking similarities between Aquinas's Third Way and Maimonides's argument in The Guide for the Perplexed, where Maimonides argues for the claim that some "existent things... are subject to generation and corruption whereas others are not" (Maimonides, The Guide for the Perplexed, II.1). Davies discusses this point in "Aquinas's Third Way" (p. 454), where he writes: "It is as sure as anything that Aquinas knew of this [Maimonides's] argument." See also: Rubio, Aquinas and Maimonides on the Possibility of the Knowledge of God, pp. 227-244. 
$\mathrm{C}$ is embedded. ${ }^{12}$ These generable and corruptible beings include, for example, "you, me, my parrot" and "the roses in my garden". ${ }^{13}$

Can all existent beings be contingent beings? And can the existence of every contingent being owe entirely to the existence of some other contingent being? Aquinas argues that the separate existences of generable and corruptible beings must ultimately owe to a necessary (i.e., ungenerable, incorruptible) being. If they did not, we would be left with an accidentally ordered series of contingent beings, none of whose members would have a nature capable of explaining the series. ${ }^{14}$ Aquinas goes on to argue that there could be nothing in existence now if all beings are mere possibles. ${ }^{15}$ But there clearly are things in existence now. Thus, on Aquinas's explanatory model it cannot be the case that all beings are contingent beings; rather, there must exist at least one non-contingent or necessary being. ${ }^{16}$

What, if anything, can we know about the number of necessary beings that can exist? In the third stage of the Third Way, Aquinas argues that there cannot exist infinitely many necessary beings that are caused by other necessary beings. Although he recognizes that there could be more than one "necessary thing", Aquinas argues that there must be a beginning to (what I call) this chain of necessary beings. ${ }^{17}$ In addition, beyond just arriving at a single, ungenerable, incorruptible being, a satisfactory account of the existence of necessary beings must also determine whether the necessity of any given necessary being is itself caused or uncaused. "Every necessary thing", Aquinas tells us, "either has its necessity caused by another, or not". ${ }^{18}$ If it is caused, then that fact just

\footnotetext{
${ }^{12}$ I thank Marilyn McCord Adams for suggesting this point.

${ }^{13}$ Davies, "Aquinas's Third Way", p. 453. Any plant and animal serves as a good example; I cite Davies's sample list because of its interesting diversity.

${ }^{14}$ Aquinas discusses this point further in ST I, q. 46, art. 2.

${ }^{15}$ This part of Aquinas's argument, which some scholars claim commits a quantifier fallacy, cannot be addressed at length in this paper. Numerous scholars (e.g., Davies, Kenny, Martin, Maritain, Wippel) have offered illuminating accounts of it.

${ }^{16}$ This part of Aquinas's argument bears an interesting resemblance to the cosmological argument advanced by Scotus. Scotus argues for the existence of an externally unproducible and independently productive nature that produces other, externally producible natures. The externally unproducible being that Scotus discusses shortly after the end of Aquinas's life is, I think, interestingly similar to Aquinas's uncaused, necessary being, whose necessity owes to itself rather than to any other being.

${ }^{17}$ Aquinas, Summa Theologica, I, q. 2, art. 3.

${ }^{18}$ Aquinas, Summa Theologica, I, q. 2, art. 3.
} 
raises the same question about the being that caused it - is that being necessary through itself? Or is it necessary through another being?

Aquinas's next move is pivotal. He claims that the causal series of beings (the necessity of each of which does not owe to the being's own nature) cannot be infinitely long (Aquinas cites an argument from the Second Way ${ }^{19}$ in support of this claim). Peter Geach nicely summarizes Aquinas's conclusion: "there must be a thing which not only is 'necessary' or imperishable, but is so underivatively or in its own right." ${ }^{20}$ This "thing" in which the chain of necessary beings must terminate is an uncaused, necessary being that is necessary through itself, and that (for reasons discussed in Section III) we can understand under the nominal definition "god". ${ }^{21}$ Constituting the absolute starting point of the chain of necessary beings, this is an immaterial rather than hylomorphic being (so it is unlike all contingent beings) that not only has its necessity entirely of its own accord, but also causes the necessary nature of all other necessary beings (the being is therefore unlike all other beings, be they necessary or contingent).

Building on the above understanding of the Third Way, Section II will address Aquinas's conception of necessary beings in the Third Way. Section III will then discuss the connection between the strongly necessary being established in the Third Way and the being that people refer to by its proper name as "God".

19 "[I]t is impossible", he explains there, "to go on to infinity in necessary things which have their necessity caused by another, as has been already proved in regard to efficient causes" (ST I, q. 2, art. 2). Aquinas's argument for the impossibility of so doing runs thus: Causes following an order have one first cause, one or many intermediate causes, and one last cause. (Incidentally, if there can be a three-cause order, why can't there be a twocause order, i.e., one without an intermediate cause?) There must be a first cause lest there not be the effects which we presently observe. Yet the existence of a backwardly infinite trail of causes would entail no first cause. It would therefore also entail no effects (which effects may be themselves further causes). Since we readily observe such effects, the chain of necessary beings must be finite.

For an interesting counterargument to this move in the Second Way, see: J.L. Mackie, "The Regress of Causes" in The Miracle of Theism, p. 90. Mackie argues that Aquinas "has simply begged the question against an infinite regress of causes".

20 Peter Geach, commentary on Aquinas from Three Philosophers, Eds. G.E.M. Anscombe and P.T. Geach (Oxford, 1961). Reprinted in Burrill, The Cosmological Arguments: A Spectrum of Opinion, p. 67.

${ }^{21}$ Some scholars, such as Martin De Nys, refer to the causes of necessity in the Third Way as "intrinsic" and "extrinsic" causes. What I have called the strongly necessary being is the only one whose necessity is "intrinsic". See: De Nys, pp. 100-102. 


\section{UNDERSTANDING THE NECESSARY BEINGS OF THE THIRD WAY}

It is no easy task to understand the concept of necessity vis-à-vis the necessary beings of the Third Way. Even highly respected scholars have misunderstood it at times. Frederick Copleston, for example, thought that Aquinas believed that "there can be but one necessary being".22 Addressing the number of necessary beings that Aquinas has in mind in the Third Way is a good step towards developing a comprehensive understanding of how he conceives of such beings. We may first note that Copleston's claim overlooks the strong support in Aquinas's writings for his belief in the existence of many necessary beings. As Patterson Brown observes, Aquinas notes elsewhere in the Summa Theologica both that "there are many necessary things in existence", ${ }^{23}$ and that "heavenly bodies, with their movements and dispositions, are necessary beings". ${ }^{24}$ These are virtually incontestable examples of Aquinas explicitly acknowledging the existence of necessary beings other than God. As to the first claim, so long as we can understand its "things" as "beings," this claim plainly contradicts Copleston's view. As to the second claim, it clearly presupposes that Aquinas conceives of God as one of many existent necessary beings such as heavenly bodies. "Aquinas never", Brian Davies avers, "speaks of God as being the only necessary being". ${ }^{25}$

Aquinas's pluralistic view of necessary beings owes partly to his Aristotelian sense of the word "necessary" in "necessary beings", to mean "ungenerable and incorruptible". As Peter Geach tells us, Aquinas held that contrary to contingent beings, necessary beings

have no inherent ability to stop existing - potentia ad non esse; for they have no matter in their make-up that could assume a different form, or split up into many pieces, or (as people have sometimes fancied) be merged in a larger whole. ${ }^{26}$

Brown nuances Geach's description:

Thomas followed Aristotle in holding that a necessary being could not begin or cease existing by any "natural" process allowed by Aristotelian

${ }^{22}$ See Copleston, A History of Philosophy, p. 363. This quotation comes from Brown, p. 78. It is of course possible that Copleston did not actually hold this view, but it is hard to refute Brown's straightforward interpretation of Copleston.

${ }^{23}$ Brown, p. 79, quoting ST I, q. 44 art. 1.

${ }^{24}$ Brown, p. 79, quoting ST I, q. 115, art. 6.

${ }^{25}$ Davies, "Aquinas's Third Way", p. 452. Emphasis original.

${ }^{26}$ Geach, in: Burrill, p. 67. Emphasis removed for reader convenience. 
physics; but Aquinas added that such beings can come into existence via creation ex nihilo, as well as pass out of existence via total annihilation. ${ }^{27}$

As Aquinas makes clear later in the Prima Pars, God can, for example, create and annihilate human souls and angels. ${ }^{28}$

It makes sense that Aquinas would arrive at an account of necessary beings by following Aristotle but with the amendment that such beings can come to exist via creation, and cease to exist via annihilation. In espousing a doctrine of supernatural annihilation and creation, Aquinas rejects Aristotle's view, discussed in De Caelo and De Generatione et Corruptione, that each of these is metaphysically impossible. ${ }^{29}$ Yet, as is his wont, Aquinas upholds an important part of Aristotle's position: $\mathrm{He}$ conceives of necessary beings as unable to undergo substantial change. ${ }^{30}$

But is it true that necessary beings cannot, under any circumstances, cease existing? One might argue (call this argument " $\mathrm{A}$ ") that they cannot cease existing by (1) citing Aquinas's claim ("C") that God permanently preserves in existence all necessary beings; and (2) arguing that, since God ensures that necessary beings will not cease existing, it is impossible for them to cease existing. ${ }^{31}$ Is there a plausible reply to this argument?

\footnotetext{
${ }^{27}$ Brown, p. 82.

${ }^{28}$ Aquinas writes about the creation of angels in ST I, q. 61, art. 1 (The Production of the Angels in the Order of Natural Being): "I answer that, It must be affirmed that angels and everything existing, except God, were made by God. God alone is His own existence; while in everything else the essence differs from the existence, as was shown above (Question 3, Article 4). From this it is clear that God alone exists of His own essence: while all other things have their existence by participation. Now whatever exists by participation is caused by what exists essentially; as everything ignited is caused by fire. Consequently the angels, of necessity, were made by God."

Further, Aquinas writes in ST I, q. 61, art. 4: “... spiritual creatures were so created as to bear some relationship to the corporeal creature, and to rule over every corporeal creature.... Hence it was fitting for the angels to be created in the highest corporeal place, as presiding over all corporeal nature."

${ }^{29}$ In De Caelo, see bk. I, ch. 11; in De Generatione et Corruptione, see bk. II, ch. 11. This point comes from Brown, p. 83.

${ }^{30}$ But it is not the case that no necessary beings can undergo accidental change (see: Brown, p. 85).

In addition, whereas contingent beings can be generated or corrupted, necessary beings, says Brown, "cannot undergo any essential change" (Brown, p. 82; I have removed his italics from this passage). The former are not subsisting beings, but the latter are.

${ }^{31}$ Quinn gives a reasonable view of such preservation/conservation: "In short, God immediately conserves beings of nature by supplying existence and mediately conserves natural species by secondary or equivocal causes" (Quinn, "A Few Reflections on 'The Third Way': Encore”, p. 84).
} 
Here is one possible counterargument:

Premise 1: Whether something (e.g., a necessary being) can cease to exist is a question of metaphysical possibility.

Premise 2: Any successful argument holding that a necessary being can or cannot cease to exist must address the metaphysical possibility of it so doing.

Premise 3: Descriptive claims about what God actually does do not address metaphysical possibility. ${ }^{32}$

Premise 4: Claim (C) above is a descriptive claim about what God actually does.

Subsidiary Conclusion: By Premise 3, (C) does not address metaphysical possibility.

Subsidiary Conclusion: By Premise 2 and the Subsidiary Conclusion above, $(\mathrm{C})$ is not germane to the question whether necessary beings can cease to exist.

Premise 5: Argument (A) (see paragraph above) depends essentially on (C), and any claim on which an argument depends essentially must be relevant to the argument's conclusion if the argument is to successfully prove that conclusion.

Main Conclusion: ${ }^{33}$ Therefore, (A) cannot successfully prove that necessary beings cannot cease to exist.

In summary, the fact that God preserves necessary beings in existence does not mean that it is metaphysically necessary that God continue to do so. Rather, since it is metaphysically possible for God to annihilate necessary beings, we may conclude with Brown that necessary beings cannot accurately be defined as "beings that cannot not-exist". ${ }^{34}$ All necessary beings are ungenerable, incorruptible beings. And since it is metaphysically possible for all necessary beings except God to be created or annihilated, it is possible for all such beings to begin existing or cease existing.

\footnotetext{
${ }^{32}$ That is, they do not address metaphysical possibility so long as God does not make one cease to exist.

${ }^{33}$ The main conclusion and rest of the argument could, of course, be worked out in smaller steps as desired.

${ }^{34}$ It also bears note that no non-God necessary being has always existed - that is, if "always" is understood as somehow going back "before" creation ex nihilo. This is a complex topic that cannot, however, be pursued in this paper in further depth.
} 
Now, as argued above, Aquinas thinks that it is not superfluous, but explanatorily necessary, to posit the existence of an uncaused necessary being that can cause the necessity of other necessary beings. An important implication of this finding for our understanding of necessary beings is this: that it helps us to arrive at the essentially ordered, causal series "God...other necessary beings". Comprising this series are what I call weakly necessary beings, ${ }^{35}$ on one hand, and the strongly necessary being, on the other. Weakly necessary beings are weakly necessary because they depend for their necessity on the strongly necessary being. The only strongly necessary being in the series - God - not only creates weakly necessary beings, but also preserves in existence both these beings and their causal and other powers. We can also say that Aquinas conceives of God as a per se cause of weakly necessary beings, on the Aristotelian view that a per se cause of a given effect is such just in case it produces that effect by its own power.

Thus we have it that God is the initial, crucial, and uncaused link in the chain of necessary beings. (We shall leave for Section III the question of whether this being is "God" or "god".) Every weakly necessary being is part of the subsequent chain of ungenerable, incorruptible beings. ${ }^{36}$ And, unlike God's existence, the existence of every such being owes to a necessary being other than itself.

The following diagram (see next page) captures two key distinctions in the Third Way: that between necessary and contingent/possible beings, and that between strongly necessary beings and weakly necessary beings.

Having understood Aquinas's conception of necessary beings in the Third Way, we are now equipped to consider three intuitively plausible but ultimately misguided interpretations of it. First, one might suppose that Aquinas is arguing for the existence of a strongly necessary being which is significant mainly because it can, and does, keep contingent beings in existence. Such a supposition is unfounded, however. "The Third Way appeals to the necessary", writes Joseph Bobik, "as to something which can account for the beginning to be of the possibles". ${ }^{37}$ It is true that Aquinas thinks that God preserves all beings in existence; however, his

\footnotetext{
${ }^{35}$ These beings may be alternatively referred to as derivatively necessary beings.

${ }^{36}$ In this chain of necessary beings there need not be efficient causal dependence of the lower beings on the higher beings.

${ }^{37}$ Joseph Bobik, "XIV. Further Reflections on the First Part of the Third Way," p. 171.
} 


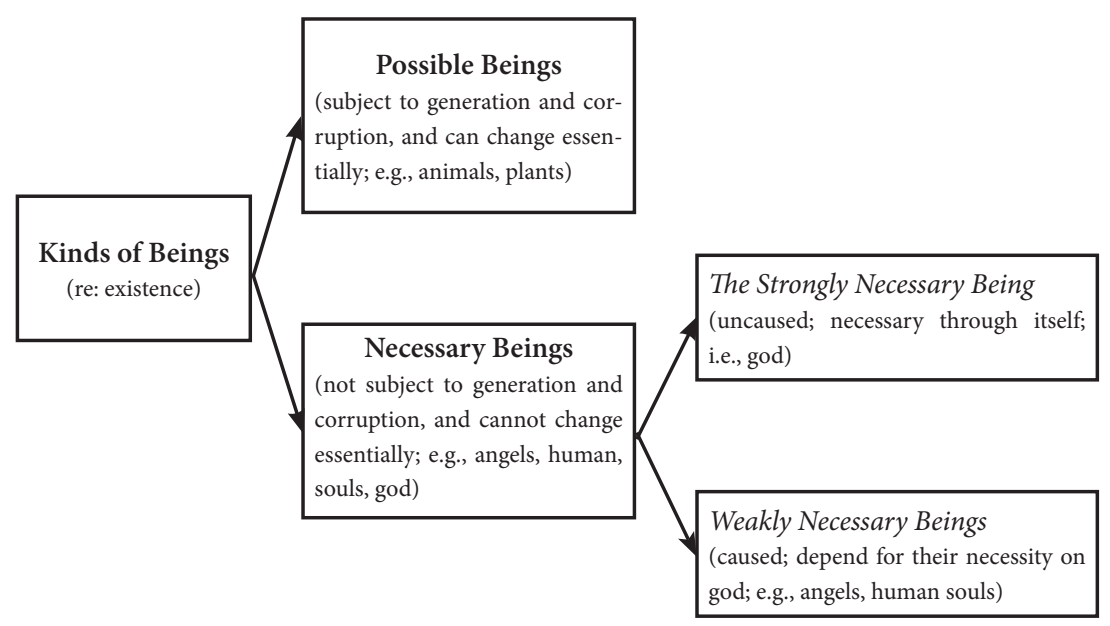

Figure 1. Possible and necessary beings as understood by Thomas Aquinas in the Third Way.

argument to this effect is to be found, not in the Third Way itself, but in a subsequent question of the Prima Pars (ST I, q. 104, art. 3). ${ }^{38}$

Second, one might suppose that, in the Third Way, Aquinas has in mind a special metaphysical connection between weakly necessary beings and the will of the strongly necessary being that is responsible for their necessity. But this supposition, too, would be unfounded. Aquinas knew that Avicenna and Averroes believed the first cause is not metaphysically free, but rather acts by natural necessity. Since Aquinas has not yet (as of this question in the Summa) ruled out the possibility of a naturally necessary first cause, any reference in the Third Way to God willing an outcome vis-à-vis other beings, be they necessary or contingent, is misplaced.

The third interpretive question about Aquinas's conception of necessary beings in the Third Way has generated a good deal of scholarly controversy: Does Aquinas have in mind logically necessary beings, or really necessary beings? Various well-respected philosophers claim that Aquinas envisions the Third Way as an argument that is primarily about

\footnotetext{
${ }^{38}$ In ST I, q. 104, art. 3, Aquinas writes: "that God gives existence to a creature depends on His will; nor does He preserve things in existence otherwise than by continually pouring out existence into them." Notably, in SCG I, c. 15, Aquinas relies upon this line of argument about God preserving all beings in existence, rendering the argument of SCG I, c. 15 importantly different from that of the Third Way.
} 
logical necessity. ${ }^{39}$ C. B. Martin states plainly that the Third Way "suggests that God's existence is logically necessary". ${ }^{40}$ Ronald Hepburn argues that the Third Way holds that "the proposition 'God exists' is necessary" such that "it would be contradictory to deny God's existence". ${ }^{41}$ And J. J. C. Smart writes that, "by 'a necessary being' ... [Aquinas's] cosmological argument means 'a logically necessary being ... whose non-existence is inconceivable in the sort of way that a triangle's having four sides is inconceivable"'. ${ }^{42}$

Contra Hepburn, Martin, and Smart, I will offer a two-fold argument to defend the claim that the Third Way is primarily about real necessity rather than logical necessity. First, as Geach writes, Aquinas was concerned in the Third Way with "the plain fact that some things are perishable" and generable. ${ }^{43}$ Aquinas's argument proceeds from observations about reality to a claim about reality (specifically, a claim about whether certain kinds of beings really do exist). Instead of taking logical axioms as its starting point, the Third Way starts with a real-world observation about the existence of generable, corruptible beings such as plants and animals, and then goes on to draw conclusions about their existence in terms of metaphysical rather than logical possibility.

Second, Aquinas rejects the notion that one can prove the existence of God simply by claiming that the proposition "God does not exist" is (logically) self-contradictory. Aquinas takes the proposition "God does not exist" to be false, but this is not based purely on logical analysis. Rather, he holds that we do not start with a concept of God that would enable us to see that God exists by God's nature. Aquinas thinks that God exists by God's essence (a complex argument which cannot be explored in detail herein), which he considers to be a metaphysical claim

${ }^{39}$ Geach notes in Burrill, pp. 65-66, that some philosophical theologians also make this argument. Although he does not name any, he does anonymously quote one such theologian.

${ }^{40}$ C. B. Martin, Religious Belief, pp. 151-152.

${ }^{41}$ Ronald Hepburn, Christianity and Paradox, p. 171.

${ }^{42}$ J. J. C. Smart, “The Existence of God" in Flew \& MacIntyre (eds.), New Essays in Philosophy Theology, pp. 35-9. In his piece "St. Thomas on Necessary Being", pp. 76-77, Brown quotes at length each of the three authors above. With gratitude to Brown, I have excerpted the key points therein for my analysis in this and the next paragraph. I agree with Brown that Aquinas is not arguing in the Third Way that God is logically necessary. In this section, I draw on and try to add to his illuminating argument for that conclusion.

${ }^{43}$ Geach, in Burrill, p. 66. Emphasis added. 
about reality, not a claim that is provable in a purely logical way. ${ }^{44}$ But he does not, for example, subscribe to Anselm's famous argument from Proslogion II according to which the proposition "God does not exist" is self-contradictory because one cannot think the concept "God" without also thinking "existence".

Furthermore, Davies tells us that Aquinas "does not think that 'God does not exist' can be proved to be contradictory apart from the supposition that God, in fact, exists". ${ }^{45}$ But why would Aquinas feel the need to bring that metaphysical supposition into the argument if it can be shown via logical analysis alone that God must exist? These considerations suggest that he does not think a purely logical proof of God's existence is possible, whether in general or in the Third Way. The two foregoing arguments, along with an important third point - that Aquinas thinks it is metaphysically possible (and therefore not logically impossible) for God to create and annihilate necessary beings other than God - suggest that Aquinas conceives of the necessity of the necessary beings in the Third Way, along with the (im)possibility of their ceasing to exist, primarily in metaphysical terms.

\section{HAS AQUINAS SUCCESSFULLY DEMONSTRATED THAT THE STRONGLY NECESSARY BEING IS GOD?}

The final section of this paper considers a key further question that has received much attention in the literature: Has Aquinas successfully demonstrated that the strongly necessary being of the Third Way is, in fact, God? One's answer to this question depends on one's conception both of the argument of the Third Way and how it relates to subsequent argumentation in the Prima Pars. Davies contends that in the Third Way, Aquinas "is assuming nothing about the divine nature". ${ }^{6}$ Aquinas is instead "simply taking it for granted that the word 'God' can be agreed to signify 'something which must be, owing this to nothing outside itself'". ${ }^{4}$ So far, so good. But Davies then makes a curious move to support his

\footnotetext{
${ }^{44}$ Aquinas's arguments that God exists by His essence, says Davies (see "Aquinas's Third Way"), is what enables him to argue in ST Ia, 2, 1 and SCG I, 10 that "God does not exist" is a self-contradictory proposition.

${ }^{45}$ Davies, "Aquinas's Third Way", p. 464, footnote 7.

${ }^{46}$ Davies, "Aquinas's Third Way", p. 463. Davies is here quoting Aquinas from Aquinas: Selected Philosophical Writings, ed. Timothy McDermott (Oxford and New York, 1993), p. 201.

${ }^{47}$ Davies, "Aquinas's Third Way", p. 463, quoting Aquinas.
} 
conclusion that the Third Way constitutes "a good defence of the claim that God exists". ${ }^{48} \mathrm{He}$ implies that this conclusion follows in part at least from his claim that most theists would agree that "God" signifies what we have called a strongly necessary being. ${ }^{49}$ This part of Davies's otherwise illuminating account seems misguided. It may indeed be the case that many theists consider God $(\mathrm{G})$ to be the strongly necessary being $(\mathrm{N})$ of the Third Way. But for Aquinas's argument to prove God's existence, it must show, not that $\mathrm{G}$ is $\mathrm{N}$, but that $\mathrm{N}$ is $\mathrm{G}$. My aim here is not to criticize Davies; rather, I mention Davies's claim as a lead-in to the central question of this section: Has Aquinas successfully proven in the Third Way that $\mathrm{N}$ is $\mathrm{G}$ ?

This question is one that many scholars are keenly aware must be addressed by those considering whether the Third Way is a successful argument all things considered. Some scholars, such as Jordan Sobel, reject the notion that Aquinas has given adequate justification for identifying N with G. In his 2004 book Logic and Theism, Sobel critiques part of the third stage of the Third Way:

With an anti-infinite-regress premise in hand, Aquinas infers correctly that there is "some being" (ST I q2, a3 p. 23) that has its necessity of itself and not (somehow) from another necessary being, but, as in the Second Way, [in the Third Way] Aquinas mistakes the proposition he has reached for the conclusion that there is some one such being, that there is exactly one such being. ${ }^{50}$

In this section, I will argue that criticisms like Sobel's trade on a misunderstanding of Aquinas's goals in the Third Way as well as his broader project in the Prima Pars. For reasons to be discussed, Aquinas was not concerned with demonstrating the oneness of God until later in the Prima Pars.

In what follows, I wish to make the case that Aquinas has not meaningfully failed in the Third Way to prove that the strongly necessary being therein is God. To that end, I will pursue a strategy suggested by John Wippel in The Metaphysical Thought of Thomas Aquinas: I will see

\footnotetext{
48"Aquinas's Third Way", p. 450. I have used a quotation from early in Davies's article because the language there is better suited than his similar language elsewhere to supporting the point just noted.

${ }^{49}$ See Davies, "Aquinas's Third Way", p. 463.

${ }^{50}$ Sobel, Logical and Theism: Arguments For and Against Beliefs in God, p. 196. Emphasis removed.
} 
whether one can establish the existence of one and only one strongly necessary being by "adopting Aquinas's procedure in q. 11" of the Summa Theologica. ${ }^{51}$ This strategy will play a key role as part of the general plan in the final section of this paper. First, I will describe Aquinas's program in the Five Ways, paying special attention to an interpretive dispute about the word "Deus" therein. Second, I will argue that Aquinas knows he must provide additional argumentation beyond that of the Third Way if he is to show that N is G (i.e., "God" with the usually understood attributes), a claim which I contend makes perfect sense given Aquinas's reliance on Aristotle's Posterior Analytics and his agenda in the Third Way. Finally, I will argue that Aquinas's project in the Third Way does not fail in the way that commentators like Sobel often claim: Aquinas undertakes a demonstration quia, the success or failure of which should be judged on the basis of his particular understanding of the Third Way vis-à-vis the Prima Pars.

In the Five Ways, Aquinas sets out to identify five features of the world that demand explanation, to posit a transcendental explainer for each, and then to suppose that the "god" which he infers as the ultimate explainer of each is, in fact, the same being in all five cases. ${ }^{52}$ Importantly, successfully identifying the being that people call "god" with God (i.e., the one and only God) depends on bridging the gap between the common noun "god" and the proper noun "God" (i.e., "God" understood as a unique appellation, signifying more than $\mathrm{N}$ alone signifies). This is a task that Aquinas undertakes subsequently in his discussion of God's attributes (e.g., simplicity, goodness, immutability) in the Prima Pars.

Now to say that something is necessary, itself uncaused, and causes others, certainly seems tantamount to describing a being that is divine in

${ }^{51}$ Wippel, p. 468. Wippel mentions, but does not pursue, this strategy toward the end of his chapter on the Third Way.

${ }^{52}$ Each feature is discussed in one of the Five Ways, which can be summarized thus. The First Way holds that a First Cause of motion is traceable from the present, observable existence of movement. The Second Way argues for the existence of a god based on the principle that efficient causes cannot extend infinitely into the past. The Third Way, as previously noted, emphasizes contingency and necessity and holds that an uncaused, necessary being (god), whose necessity owes entirely to itself, must be the cause not only of all other necessary beings but also of all of the readily observable contingent beings. The Fourth Way argues that the fact that beings have various degrees of goodness, truth, and so on, means that there must be some being which is the maximum in each relevant genus, and we call this being God. The Fifth Way holds that there must exist an intelligent being - god - that is directing natural things to their ends. 
nature. If we call such a being $\mathrm{N}$, the reader can easily accept the claim that $\mathrm{N}$ can be called god (or, we might say, "a god"). This claim is true even if nothing more than $\mathrm{N}$-ness (i.e., having the character of a strongly necessary being) is assumed, as yet, as an attribute of this divine being. In what follows, I will use the lower-case term "god" (or "a god") to denote the divine being arrived at in the Third Way, and the upper-case term "God" to denote God as commonly understood. Finally, we might consider "God" in this sense as akin to an $\mathrm{N}^{*}$ : a strongly necessary being that also has the attribute of oneness.

Much of the disagreement about the third stage of the Third Way derives from interpretive confusion surrounding Aquinas's use of the word "Deus". Some of this confusion owes to the absence in Latin of both definite and indefinite articles. Without these articles, one sometimes cannot be sure of the kind of being to which a given author is referring. (For example, is it: (a) a god; (b) god in the abstract; (c) the god; or (d) God under a proper name?) A good example of esteemed philosophers putting forward a contestable account of "Deus" is that of McInerny and O'Callaghan, who imply that Aquinas does not use "Deus" in any of the Five Ways, but instead uses "deus" ${ }^{33}$ This claim is not verified, however, by my consultation of important modern editions of the Summa Theologica, including the Leonine Edition, which use "Deus". ${ }^{4}$ Without becoming enmeshed in a thorny debate over capitalization in early versions of the Latin Summa Theologica, we can still make use of McInerny and O'Callaghan's point that the word I have stipulated as the lowercase "god" (however the corresponding Latin word appears) is intended as a "common noun having five different nominal definitions". ${ }^{55}$ It also seems appropriate to translate "Deus" (or "deus"-again, however the word appears) in the Third Way as "god" meant in a quite general sense. It would then mean something like "divinely natured being" (in the abstract) or, with the indefinite article, "a divinely natured being". The proposed sense of "Deus" signifies that this being's uniqueness has not

${ }^{53}$ McInerny and O'Callaghan, p. 26. In this section I draw gratefully on McInerny and O'Callaghan's account of the Five Ways in "St. Thomas Aquinas", pp. 26-27 (Section 10.1).

${ }^{54}$ And even if some versions of the Summa Theologica use "deus" in the Third Way, many Latin works during and even after Aquinas's lifetime - e.g., the 1480 edition of the Glossa Ordinaria - do not consistently capitalize "deus" when the word is used in the middle of sentences and obviously refers to the Christian God (i.e., using "deus" where we would use "Deus").

${ }^{55}$ McInerny and O’Callaghan, p. 26. 
yet been established, nor has there yet been argument for its possession of attributes besides those of $\mathrm{N}$.

The second piece of the puzzle concerning whether Aquinas succeeds in the Third Way regards Aquinas's reliance on Aristotle's Posterior Analytics. McInerny and O'Callaghan nicely summarize how the Posterior Analytics influenced the way in which Aquinas thought an argument must run if it is to proceed from (1) proving the existence of a god (i.e., the uncaused, necessary being of the Third Way) to (2) demonstrating the existence of God. They write:

[I]n terms of the Posterior Analytics one cannot demonstrate the existence of anything under a proper name. One can point at Socrates, and say 'see, Socrates is alive'. One cannot do that with God. In addition, one cannot give a formal argument for Socrates [sic] existence using 'Socrates'. One can only demonstrate in the relevant sense using common nouns, since such nouns are the only ones that have definitions, either nominal or essential. So strictly speaking it is true that Aquinas doesn't think one can demonstrate the existence of God in the Five Ways. But he doesn't claim that one can. He recognizes the difference between 'God' used as a proper noun, and 'god' used as a common noun. ${ }^{56}$

This passage suggests that, if Aquinas does not prove the existence of God (as a proper name) in the Third Way, this should not be understood as reflecting poorly on the strength of his argument therein.

The preceding conclusion holds in large part because of Aquinas's epistemology and, specifically, how it constrains his efforts to prove God's existence. Since one cannot undertake a demonstration propter quid without knowledge of God's essence, but Aquinas rejects the notion that we can know God's essence, it makes sense that Aquinas instead carries out a demonstration quia. ${ }^{57}$ Aquinas arrives in the Third Way at knowledge of the existence of a lowercase-g god by using a nominal definition and relying on knowledge of that being's effects. Included among these effects is the existence of generable, corruptible beings. Yet neither the individual nor the collective existence of such

\footnotetext{
${ }^{56}$ McInerny and O’Callaghan, pp. 26-27.

${ }^{57}$ Christopher Shields nicely summarizes Aristotle's understanding of a demonstration and the relation of it to science (in Aristotle's oeuvre, see: APo 71b33-72a5, Phys. 184a16-23, EN 1095b2-4): "The currency of science is demonstration (apodeixis), where a demonstration is a deduction with premises revealing the causal structures of the world, set forth so as to capture what is necessary and to reveal what is better known and more intelligible by nature" (Shields, "Aristotle," p. 13).
} 
beings is explicable in terms of any single member of, or group within, the set of all generable, corruptible beings. With further argument as described earlier in this paper, Aquinas eventually arrives at the existence of a strongly necessary being. This way of arguing is, of course, far different from that of starting with an essential definition of "God" and then deriving attributes of God from knowledge of God's essence. Since Aquinas thought it was impossible to carry out a propter quid demonstration of God's existence, he had to arrive at a capital-G God via other means. So Aquinas sought to prove god's existence in a somewhat minimal sense in the Third Way, and then to fill out that proof subsequently in the Prima Pars.

A key place where Aquinas fills out his argument from the Third Way is in ST I, q. 11, art. 3, where he argues that there exists one and only one strongly necessary being. I will conclude this section by discussing the crucial way in which this argument helps Aquinas get from "god" to "God"; i.e., from N to G. The following comment by Wippel makes clear that there is a real need for such a discussion: "Additional reflection", he concedes, would be required "to show that there is only one first and totally uncaused necessary being if we are to justify the claim that this being is God". ${ }^{8}$ Importantly, the oneness of God is surely one of the principal attributes commonly assumed in discussions about capital-G God.

In ST I, q. 11, art. 3, Aquinas puts forward three arguments for the conclusion that God is one. First, God is His own nature and therefore is not many, different natures. Second, if there were many gods, it would be impossible for each of them to possess all perfections. Support for this second claim comes from two noteworthy metaphysical views that Aquinas holds. First, there can be no distinction of form among many gods. Second, if there existed many gods, they would lack the material needed for them to be distinguished via material individuation, since they are not hylomorphic composites after all. Thus, there can be only one god. Aquinas's third argument for the conclusion that capital-G God must be one holds that God is the first, perfect, per se cause to which all other beings are ordered, since "things that are diverse do not harmonize in the same order, unless they are ordered thereto by one". ${ }^{59}$ Aquinas twice states his main conclusion in art. 3: "Impossible is it ... that many

\footnotetext{
${ }^{58}$ Wippel, p. 468.

${ }^{59}$ Aquinas, Summa Theologica 1, q. 11, art. 3.
} 
Gods should exist." (Incidentally, the argumentation in q. 11 also reveals why there cannot be two "chains" of necessary being, each of which goes back to a different uncaused, necessary being.)

Aquinas is aware that the existence of a given necessary being does not entail the existence of God with all of God's attributes. Consequently, Aquinas not only defends the ascription of oneness to the necessary being, but also takes this being to be the transcendental explainer of each of the features of the world that are discussed in the Five Ways. We might say that Aquinas's argument in ST I, q. 11, art. 3 crucially "upgrades" his proof of the existence of a god in the Third Way to a proof of the existence of God in the Prima Pars. For, "once the utter uniqueness of a god has been shown", write McInerny and O'Callaghan, "one can begin to use 'God' as a proper name to refer to that utterly unique being". ${ }^{60}$ This important claim can be unpacked as follows. If one can formulate both a strong argument "A" for the existence of "a god", and a strong argument " $\mathrm{B}$ " for the uniqueness of any god, then one can, by combining $A$ and $B$, plausibly demonstrate the existence of a being that may be appropriately called "God". ${ }^{61}$ Of course, Aquinas's "God" has many philosophically discussable attributes beyond just utter uniqueness (e.g., simplicity, goodness, immutability); the nature of these attributes is fleshed out in other questions of the Summa Theologica. Yet, once it has been shown that oneness attaches to the "divinely natured being" (in the abstract) or "a divinely natured being" (what I have called "god" or "a god"), then the link from $\mathrm{N}$ to $\mathrm{G}$ has been made.

Now there is a reason why the title of this section is the following ambiguous question: Has Aquinas successfully demonstrated that the strongly necessary being is God? The ambiguity lies in the fact that any answer to this question depends on what one means by "success" vis-à-vis Aquinas's argument in the Third Way. From one perspective, it is clear that

${ }^{60}$ McInerny and O'Callaghan, p. 27. Though Aquinas sometimes treats the word "God" as a common noun, it bears emphasis that McInerny and O'Callaghan's discussion accords with Peter Geach's analysis in "Form and Existence". Geach notes that when Aquinas uses "God" in certain contexts (e.g., in phrases such as "the wisdom of God"), the word "has the force of a definite description" that "can significantly take the place of a proper name". See Geach, "Form and Existence", p. 122, in Aquinas's Summa Theologiae: Critical Essays (ed. Brian Davies).

${ }^{61}$ This claim depends on whether there is ample reason to consider an utterly unique, strongly necessary being "God". Duly addressing that consideration would require another paper in itself. 
Aquinas does not "succeed" at such a demonstration in the Third Way. After all, he arrives at N, not G. And yet, it was not Aquinas's intention in the Third Way to advance a freestanding argument for God's existence. In general, any fair standard by which to judge the success (or failure) of the Third Way must account for Aquinas's own conception of the relationship between the Third Way and his subsequent argumentation in the Prima Pars. A key implication of this fact is that any claim that the Third Way fails because it does not prove that $\mathrm{N}$ is $\mathrm{G}$ is finally not very meaningful. ${ }^{62}$ The conclusion of this section, then, is that the Third Way should be viewed as part and parcel of a far broader argument for the existence of the one, unique God. This argument seems plausible enough given the preceding analysis, or at least more plausible than it is often considered to be.

\section{CONCLUSION}

Aquinas's Third Way begins with a straightforward observation about the world, namely, that certain beings are possible or (we may say) contingent. The conclusion at which it ultimately arrives is that there must exist a necessary being whose necessity owes to that being itself rather than to some other being. After presenting the text and the context of the Third Way, I argued for a particular understanding of Aquinas's conception of necessary beings vis-à-vis the Third Way. I argued that, contra the views of scholars like Copleston, Aquinas believes that there exists a plurality of necessary beings. These beings are necessary, moreover, because they are ungenerable and incorruptible, not because they cannot cease to exist unaffected, say, by God's operations. I also proposed the terms "weakly necessary beings" (e.g., human souls, angels) and "strongly necessary being" (i.e., God), which respectively correspond to whether a given necessary being is caused or uncaused. Furthermore, against the views of scholars like Martin, Hepburn, and Smart, I argued that Aquinas conceives of the Third Way as dealing with really necessary beings, not logically necessary ones. After all, Aquinas posits the existence of a strongly necessary being to account for the apparent (real, not logical) fact that the world can neither consist entirely of contingent beings, nor

${ }^{62}$ There are of course legitimate reasons to question the plausibility of the Third Way, as there are for just about any complex argument. 
contain infinitely many necessary beings whose necessity is "caused by another". 63

In Section III, I argued that it is not particularly meaningful (though not false strictly speaking), to charge Aquinas with failing to prove the existence of capital-G God in the Third Way. The way in which Aquinas relies on Aristotle's Posterior Analytics strongly suggests that he conceives of the Third Way as dependent on additional argumentation such as that found in ST I, q. 11, art. 3. Brown puts this point nicely when he suggests "that St. Thomas was, in the last two sentences of the Third Way, tacitly presupposing his own proof regarding uniqueness". ${ }^{64}$

This paper was written with two related aims in mind. The first was to produce a focused analysis of the conception of necessary beings upon which Aquinas relies in the Third Way. The second was to emphasize why Aquinas's identification of the strongly necessary being with God requires argumentation beyond that found in the Third Way, and to indicate the import of that fact for how one should judge the success or failure of the Third Way. If the analysis in this paper is basically accurate, my hope is that this paper will help clear up some of the existing analytic and interpretive confusion surrounding the necessary beings of Aquinas's Third Way.

\section{BIBLIOGRAPHY}

Allen, Diogenes, and Eric O. Springsted. Philosophy for Understanding Theology (second ed.), (Louisville: Westminster John Knox Press, 2007)

Aquinas, Thomas. Summa Contra Gentiles. Dominican Fathers (Leonine Edition), 1924. Available at: URL $=<$ http://www.archive.org/stream/ summacontragenti01thomuoft/summacontragenti01thomuoft_djvu.txt> (Accessed 9 June 2011)

Aquinas, Thomas. Summa Theologica. Fathers of the English Dominican Province, 2008. Available at: URL $=<\mathrm{http} / /$ www.newadvent.org/summa/1002.htm $>$ (Accessed 8 May 2011)

Aristotle. The Complete Works of Aristotle, Vol. 2. Ed. Jonathan Barnes. Bollingen Series. (Princeton: Princeton University Press, 1984)

Bobik, Joseph. "XIV. Further Reflections on the First Part of the Third Way", Philosophical Studies XIV (1972), 166-174

\footnotetext{
${ }^{63}$ Aquinas, ST I, q. 2, art. 3.

${ }^{64}$ Brown, p. 89.
} 
Boundas, Constantin, ed. Columbia Companion to Twentieth-Century Philosophies,

(New York: Edinburgh University Press, 2007)

Brown, Patterson. "St. Thomas's Doctrine of Necessary Being", The Philosophical Review, 73, no. 1 (Jan. 1964), 76-90.

Burrill, Donald R., ed. The Cosmological Arguments: A Spectrum of Opinion, (New York: Anchor Books, 1967)

Copleston, Frederick. A History of Philosophy, (London: Doubleday, 1959)

Davidson, Matthew. "God and Other Necessary Beings", The Stanford Encyclopedia of Philosophy. 29 April 2005. Available at: URL $=<$ http://plato. stanford.edu/entries/god-necessary-being/> (Accessed 4 May 2011)

Davies, Brian. "Aquinas's Third Way", New Blackfriars, 968, no. 82 (Oct. 2001), 450-468

Davies, Brian, ed. Aquinas's Summa Theologiae: Critical Essays, (Lanham, MD: Rowman and Littlefield, 2006)

De Nys, Martin J. "If Everything Can Not-Be, There Would be Nothing: Another Look at the Third Way", The Review of Metaphysic

$s$, 56, no. 1 (Sept. 2002), 99-122

Flew, Antony, and Alasdair MacIntyre, eds. New Essays in Philosophical Theology, (New York, 1955)

Hepburn, Richard. Christianity and Paradox, (London: Humanities Press, 1958)

Hume, David. A Treatise of Human Nature. Ed. L. A. Selby-Bigge, (Oxford: Oxford University Press, 1978)

Kelly, Thomas A. F. "Ex Possibili et Necessario: A Re-examination of Aquinas's Third Way", The Thomist 61 (1997). Available at: URL $=<\mathrm{http}: / / \mathrm{www}$. thomist.org/journal/1997/971AKell.htm> (Accessed 20 May 2011)

Kenny, Anthony. The Five Ways, (New York: Schocken Books, 1969)

Mackie, J. L. "The Regress of Causes" in The Miracle of Theism, (Oxford: Oxford University Press, 1982)

Maritain, Jacques. Approaches to God, (New York: Harper \& Brothers Publishers, 1954)

Martin, C. B. Religious Belief, (Ithaca, New York: Cornell University Press, 1959)

Martin, C. F. J. Thomas Aquinas: God and Explanations, (Edinburgh: Edinburgh University Press, 1997)

Mautner, Thomas. "Aquinas's Third Way", American Philosophical Quarterly, 6, no. 4 (Oct. 1969), 298-304

Maydole, Robert E. "Aquinas' Third Way Modalized", Philosophy of Religion. Available at: URL $=\langle$ http://www.bu.edu/wcp/Papers/Reli/ReliMayd.htm $>$ (Accessed 20 May 2011)

McInerny, Ralph, and John O'Callaghan. "Saint Thomas Aquinas", The Stanford Encyclopedia of Philosophy. 30 September 2009. Available at: URL $=<$ http:// plato.stanford.edu/entries/aquinas/> (Accessed 15 May 2011) 
Min, Anselm K. Paths to the Triune God, (Notre Dame, Indiana: University of Notre Dame Press, 2005)

Pasnau, Robert, and Christopher Shields. The Philosophy of Aquinas, (Boulder, CO: Westview Press, 2004)

Plantinga, Alvin. God and Other Minds, (Ithaca: Cornell University Press, 1967)

Quinn, John M. "A Few Reflections on 'The Third Way': Encore", Thomist: A Speculative Quarterly Review, 46, no. 1 (Jan. 1982), 75-91

Reichenbach, Bruce. "Cosmological Argument", The Stanford Encyclopedia of Philosophy. September 11, 2008. Available at: URL $=<$ http://plato.stanford. edu/entries/cosmological-argument/> (Accessed 12 May 2011)

Rubio, Mercedes. Aquinas and Maimonides on the Possibility of the Knowledge of God, (Dordrecht, The Netherlands: Springer, 2006)

Shanley, Brian J. The Thomist Tradition, (London: Kluwer Academic Publishers, 2002)

Shields, Christopher. "Aristotle", The Stanford Encyclopedia of Philosophy. September 25, 2008. Available at: URL $=<$ http://plato.stanford.edu/entries/ aristotle/> (Accessed 21 July 2011)

Smart, J. J. C. and J. J. Haldane. Atheism and Theism, (Oxford: Blackwell, 1996)

Sobel, Jordan H. Logic and Theism: Arguments For and Against Beliefs in God, (Cambridge: Cambridge University Press, 2004)

Ward, Keith. Why There Almost Certainly Is a God: Doubting Dawkins, (Oxford: Lion Hudson, 2008)

Wippel, John F. The Metaphysical Thought of Thomas Aquinas: From Finite Being to Uncreated Being, (Washington, D.C.: The Catholic University of America Press, 2000) 